\title{
Evaluating Performance of Cherry and Slicer Tomato Cultivars in Greenhouse and Open Field Conditions: Yield and Fruit Quality
}

\author{
Hardeep Singh, Bruce Dunn, Niels Maness, Lynn Brandenberger, \\ Lynda Carrier, and Bizhen Hu \\ Department of Horticulture and Landscape Architecture, $358 \mathrm{Ag} \mathrm{Hall,}$ \\ Oklahoma State University, Stillwater, OK 74078-6027
}

Additional index words. fruit size, hydroponics, lycopene content, Solanaceae, taste analysis

\begin{abstract}
Tomato (Solanum lycopersicum L.) is one of the most extensively cultivated horticultural crops in the world. Factors such as yield, size, taste, and lycopene content are important criteria that may impact the selection of tomato cultivars for different production systems. The aim of the current study was to evaluate different slicer and cherry tomato cultivars for production under greenhouse and open field conditions. Three cultivars of slicer (BHN 964, Trust, and Geronimo) and cherry (BHN 268, Favorita, and Sakura) tomatoes were tested using randomized complete block design in 2019 and 2020. Results showed that the performance of tested cultivars differed under greenhouse verses open field conditions. Among cherry tomato cultivars in 2020, BHN 268 and Sakura produced significantly greater yield under open field conditions, while under greenhouse conditions yield of BHN 268 was the lowest. Similarly, cherry tomato fruit size from 'BHN 268' and 'Sakura' was also significantly greater than 'Favorita' under field conditions, whereas under greenhouse conditions, the fruit size of 'Sakura' was significantly greater than both 'BHN 268' and 'Favorita'. Among slicer tomato cultivars, BHN 964 produced significantly greater yield and had a greater average fruit size than the other two cultivars under greenhouse conditions in 2020 while, Geronimo produced significantly similar or larger yield and had a similar average fruit size compared with BHN 964 under open field conditions. Tomatoes produced under open field conditions were rated significantly greater for taste compared with those produced under greenhouse conditions. Lycopene content in both slicer and cherry tomato cultivars was influenced by the interaction of production type, cultivars, and harvest time. Therefore, it can be concluded that BHN 964 and Geronimo were the highest in lycopene among slicer tomato cultivars for greenhouse and open field production, respectively. Among cherry tomato cultivars, BHN 268 was the highest in lycopene for open field production and Sakura for greenhouse production. Additionally, open field-produced tomatoes taste better than greenhouse-produced tomatoes, but lycopene content may be constrained for mid- and late-season fruits due to high temperature conditions under open field conditions.
\end{abstract}

Tomato is the second most consumed vegetable crop in the United States after potatoes (Reimers and Keast, 2016), and the United States is the second largest producer of tomatoes after China (Guan et al., 2017). In 2018 , the United States produced $\approx 1.09$ million tons of fresh market tomatoes and 12.8 million tons of processing tomatoes on 321,900 acres with a total value of about $\$ 1.85$ billion (Cornell University, 2018). This production area included different production systems such as open field, greenhouse, and high tunnel. Each production system has its

Received for publication 18 May 2021. Accepted for publication 25 May 2021.

Published online 9 July 2021.

B.D. is the corresponding author. E-mail: bruce.dunn@okstate.edu.

This is an open access article distributed under the CC BY-NC-ND license (https://creativecommons. org/licenses/by-nc-nd/4.0/). the consumers concerned with food safety issues (Cook and Calvin, 2005). To overcome these problems, the use of protected cultivation structures for tomato production has gained widespread interest since the 1950s with the introduction of polyethylene in agriculture applications.

Protected cultivation structures, such as greenhouses or high tunnels, are considered the best choice for high-value horticultural crops such as tomato. It is because tomatoes can generate greater revenue compared with many other crops, allowing quick recovery of the initial investment and ongoing income to sustain management expenses (O'Connell et al., 2012). Greenhouse-grown tomatoes constitute $\approx 37 \%$ of the quantity and $39 \%$ of the value of all retail fresh market tomatoes sold in the United States (Jones, 2008). Greenhouse tomato production may be carried out using soil or hydroponic growing systems (Jensen, 1997). The most common hydroponic systems used in greenhouse production of tomatoes are rockwool slabs and Dutch bucket systems (Morgan, 2003). Research that explored horticultural production under protected cultivation structures in the United States indicated a variety of positive benefits from Dutch bucket system (O'Connell et al., 2012).

The yield of different crops is reported to be greater under greenhouse production compared with open field production (Csizinsky, 2005; Peet and Welles, 2005). According to the Greek Ministry of Rural Development and Food, the average tomato yield from open field production systems amounted to $23.02 \mathrm{t} \cdot \mathrm{ha}^{-1}$, whereas average tomato yield from greenhouse production systems was $112.59 \mathrm{t}^{\mathrm{ha}} \mathrm{ha}^{-1}$ and thus $\approx 5$ times greater (Savvas et al., 2015). Padmanabhan et al. (2016) also reported that tomato production under greenhouse conditions could be increased $\approx 15$ times compared with open field production. However, it is important to select appropriate cultivars for obtaining economically viable tomato yields under different production systems. In open field production, determinate-type tomato cultivars are primarily recommended, whereas indeterminate type tomato cultivars are recommended for greenhouse production (Thaxton and Hochmuth, 2015). Additionally, cultivars for specific production systems can also be determined based on their shelf life, with longer shelf-life cultivars selected for open field production (Figas et al., 2018).

In addition to yield differences, different production systems may also influence the quality of the produce. Color is an important characteristic of the eating quality, for which pigments are responsible. In tomato fruit, more than 21 pigments from the carotenoid class have been identified. Red color of tomatoes is mainly due to lycopene, which is the most abundant carotenoid (83\%) in ripe tomatoes (Dávila-Aviña et al., 2011). However, carotenoid biosynthesis can be influenced by environmental conditions during fruit development. According to Farkas (1994), lycopene production is inhibited when temperature is above $32{ }^{\circ} \mathrm{C}$. Therefore, tomato production under 
different cropping systems may influence the lycopene content and affect the quality of the tomato fruits. Dávila-Aviña et al. (2011) also reported that lycopene content of greenhouse produced tomatoes $\left(83.0 \mathrm{mg} \cdot \mathrm{kg}^{-1}\right.$ fruit weight) was significantly greater than that of the open field-produced tomatoes $\left(59.2 \mathrm{mg} \cdot \mathrm{kg}^{-1}\right.$ fruit weight).

Information regarding greenhouse production of tomatoes in Oklahoma is limited. Exploration of the use of greenhouse production systems would help growers to generate more income by providing off-season yearround supply of tomatoes to local and regional markets. Additionally, little is known about how different cultivars perform under different production systems. Therefore, our study objective was to evaluate different cherry and slicer tomato cultivars under open field and greenhouse production systems for yield potential and fruit quality (taste and lycopene content).

\section{Materials and Methods}

Plant materials and growing conditions. Seeds of cherry tomato cultivars BHN 268, Favorita, and Sakura were obtained from Rupp Seeds (Wauseon, OH), Paramount Seeds (Stuart, FL), and Jonny's Selected Seeds (Winslow, $\mathrm{ME}$ ), respectively. Slicer tomato cultivars BHN 964, Geronimo, and Trust were from Rupp Seeds, Jonny's Selected Seeds, and De Ruiter Seeds (Cambridge, UK), respectively. For greenhouse production, experiments were conducted at Oklahoma State University Department of Horticulture and Landscape Architecture Research Greenhouses (36.13602913, 97.08619773; Stillwater, OK). Two identical greenhouses were used for conducting experiments. A $40 \%$ shadecloth was installed, and greenhouse temperatures were maintained at $24 / 18^{\circ} \mathrm{C}$ (day/night) in both greenhouses. Plants were grown under natural photoperiods. Seeds were planted in oasis cubes (Greenhouse Megastore, Danville, IL) on 19 Jan. 2019 (firstyear experiment) and 7 Feb. 2020 (second-year experiment). Seedlings were transplanted into the hydroponic Dutch bucket systems on 18 Mar. 2019 and 25 Mar. 2020, respectively. Hydroponic fertilizer Peter's 5N-4.8P-21.6K (J.R. Peters, Allentown, PA) was used for nutrition. There was one plant per bucket, and plants were trellised and pruned to a single stem. The $\mathrm{pH}$ and electrical conductivity of nutrient solution were maintained at 5.5 to 6.5 and 1.5 to 2.5 , respectively (Singh and Dunn, 2016). The Dutch buckets were placed $50 \mathrm{~cm}$ apart, and the rows were $100 \mathrm{~cm}$ apart and arranged on the opposite side of the irrigation and drainage pipes.

Field experiments took place at the Botanic Garden at Oklahoma State University during both years (36.11968994140625, - -97.1015472 4121094; Stillwater, OK). In years 1 and 2, tomato seeds were sown into soilless media (Sun Gro Horticulture, Bellevue, WA) in finish containers [4 × 9 (36-cell) six packs; Landmark Plastic Corporation, Akron, OH] on 15 Mar. 2019 and 9 Mar. 2020, respectively. Preparation for field transplanting included mowing of standing cover crops, strip-tilling with a tractor powered rototiller, and then formation of free-standing raised beds and installation of drip irrigation line (TORO AQUA-TRAXX 5/ 8"; Toro Company, Bloomington, MN). Preparation also included the addition of $\approx 2.24$ t $\cdot \mathrm{a}^{-1}$ of spent mushroom compost after mowing before tilling in 2020. A Rain-Flo singlerow bed shaper (Model 2550; Rain-Flo, East Earl, PA) was used both years for shaping beds and drip irrigation line installation. Beds were spaced $300 \mathrm{~cm}$ apart from the center of each bed, and plots were $365 \mathrm{~cm}$ long. Field preparation was completed on 16 May 2019 and on 20 Apr. 2020.

Tomatoes were transplanted by hand into plots on 16 May 2019 and 21 Apr. 2020 with in-row spacing at $60 \mathrm{~cm}$ apart with a total of six plants per plot. Following transplanting, herbicide (2019, halosulfuron at a rate of $26.89 \mathrm{~g} \cdot \mathrm{ha}^{-1}$; Gowan, Yuma, AZ) and (2020, pendimethalin at rate of $2,338.49 \mathrm{~mL} \cdot \mathrm{ha}^{-1}$; BASF Corporation, Research Triangle Park, NC) was applied to the soil surface for weed control. This was followed by the application of a clean-straw mulch 2 weeks later for weed control and soil temperature management during both years. After transplanting in 2019 , the site received additional heavy rains $(\approx 431 \mathrm{~mm}$ ), which caused erosion, and some plants were replaced the following week. Tomato support was managed both years using the stake and weave method, which used baling twine and metal pipes for plant support. Plants were fertilized through the drip irrigation system using a swimming pool chlorinator (Pentair R171218 In-Line Chlorinator 320C; Pentair, Cary, NC) to deliver fertilizer. Nutrient needs of the crop according to soil test results were met by using blossom booster fertilizer $(10 \mathrm{~N}-13.1 \mathrm{P}-16.6 \mathrm{~K}$; J.R. Peters, Inc.) and urea ( $46 \mathrm{~N}-0 \mathrm{P}-0 \mathrm{~K})$ to provide an equivalent rate of $74 \mathrm{~N}-38.0 \mathrm{P}-48.1 \mathrm{~K}$ $\mathrm{kg} \cdot \mathrm{ha}^{-1}$ in 2019 and $93 \mathrm{~N}-14.9 \mathrm{P}-18.3 \mathrm{~K}$ $\mathrm{kg} \cdot \mathrm{ha}^{-1}$ in 2020. Insect pests included tobacco horn worm, yellow-striped armyworms, stinkbug, and harlequin beetle which were treated with Permethrin (111.15 g.ha ${ }^{-1}$ a.i.; PermaStar, LG Life Sciences America, Inc., Englewood Cliffs, NJ) once in 2019 and twice in 2020.

Fruit harvest. For greenhouse production, each year the harvest was begun on 16 May and continued until 7 Oct. For field production, the first-year experiment harvest began on 12 July 2019 and last harvest was recorded on 4 Sept. 2019 resulting in a total of 13 harvests. The second-year field production harvest began on 15 June 2020 and continued until 31 Aug. 2020, with a total of 13 harvests were recorded for both production systems. Harvested fruits were determined as marketable or culls, and marketable fruits were counted then weighed for each plot. Data collected included number of fruits, total fruit weight, and average fruit weight.

Taste analysis. After recording the yield data from both production systems, representative tomato fruits of each cultivar were used for taste analysis. An informal taste panel, which included 15 people in 2019 and 20 people in 2020 was organized and carried out in August with available fruit from both field and greenhouse. Tomatoes were cut into small bite-sized pieces and placed on a plate divided into nine sections. Each plate was given a specific number as tomato piece placement was randomized on each individual plate. The varieties were not separated by type. Participants were asked to rate them on a 0 to 10 hedonic scale. Most desirable taste rated as 10 and a 0 would be undesirable flavor.

Laboratory analysis. Tomatoes from the early, mid, and late portions of the harvest season were obtained from the field and greenhouse for laboratory analysis. Usually, one red tomato from the slicer varieties was selected for lycopene determination. Depending on size of the cherry tomatoes, four to seven red tomatoes were selected for processing. Tomatoes were diced and added to a grinding vessel and pureed with an OmniMixer homogenizer fitted with a $10 \mathrm{~mm} \times$ $195 \mathrm{~mm}$ fine saw tooth generator probe (Omni International, Kennesaw, GA) for 1 to 3 min on ice. After grinding, lycopene content was measured spectrophotometrically using a modification of the procedure of Sadler et al. (1990) as follows: 1 to $1.2 \mathrm{~g}$ of pureed sample was added to a $120-\mathrm{mL}$ brown bottle containing $50 \mathrm{mg}$ butylated hydroxytoluene. Twenty-five milliliters of $95 \%$ ethanol was then added, followed by $50 \mathrm{ml}$ hexane and $25 \mathrm{ml}$ acetone. Samples were then ground for $30 \mathrm{~s}$ with the Omni-Mixer homogenizer on ice. Bottles were securely capped and placed on shaker for $10 \mathrm{~min}$ at $100 \mathrm{rpm}$ at 21 to $22^{\circ} \mathrm{C}$. Fifteen milliliters of deionized water was added to each bottle and shaken vigorously for $1 \mathrm{~min}$ by hand. Samples were then allowed to stand for 15 to 20 min after which a fraction of the top hexane layer was removed for spectrophotometric analysis. Lycopene was quantified with a dual beam Shimadzu spectrophotometer at $503 \mathrm{~nm}$ (Shimadzu ultraviolet-160U Visible Recording Spectrophotometer; Shimadzu Scientific Instruments, Houston, TX). The $\mu \mathrm{g} \cdot \mathrm{g}^{-1}$ per sample was calculated by the following formula:

$\left\{\frac{(\text { Abs @ } 530 \mathrm{~nm} / 0.172) \times \text { Organic volume used }(\mathrm{ml})}{\text { weight of the samples }(\mathrm{g})}\right\}$

$\times 0.5369$,

where Abs@503 nm is the spectrophotometric absorbance units as given by the instrument; 0.172 is the extinction coefficient of lycopene in hexane; organic volume stands for the volume in milliliters of the hexane used for extraction; weight of the sample used for extraction is in grams and 0.5369 is the molecular weight of lycopene divided by $1000(536.9 \mathrm{~g} / \mathrm{M})$.

Experimental design. For greenhouse production, the experimental design was a randomized complete block design where a single greenhouse acted as a complete block. The treatments included three cherry and three slicer tomato cultivars. Within a block (greenhouse), each cultivar had five single plant replicates, 
and there were two greenhouses. The whole experiment was replicated the following year. The observational unit was a single plant and experimental unit was set of five plants of a single treatment within a greenhouse.

For open field production, the experimental design was a randomized complete block design. Treatments included three cherry and three slicer tomato cultivars. There was a total of six plants per treatment plot and each treatment plot was replicated three times. The experimental and observational unit for the open field production was the same, which was a whole treatment plot (or set of six plant). The experiment was repeated in the same way in year 2.

Data analysis. For yield data, production system was not considered as a factor as the systems were not comparable due to design differences (number of replications and plants). The difference of measured variables among the treatments were determined using a one-way analysis of variance in SAS 9.4 (SAS Inc., Cary, NC). The block was treated as a random effect. The normality of data were tested using Shapiro-Wilk test and homogeneity of variances was tested using Levene's test.

For laboratory and taste analysis, production system was considered as a factor, and data were analyzed as a factorial treatment. Factors were production systems (two levels: field and greenhouse) and different cultivars of cherry and slicer tomatoes (three levels of each type of tomato). Therefore, treatment structure for laboratory and taste analysis was $2 \times 3$ factorial. The difference of measured variables among the treatments were determined using mixed models in SAS 9.4. The least significance difference method was used for comparing differences between treatment means at a significance level of 0.05 .

\section{Results}

Field production. During the first year's experiment, there was no significant difference among cherry tomato cultivars for marketable yield (yield mass), whereas Favorita produced significantly greater number of marketable fruits as compared with that produced by BHN 268 (Table 1). The number of marketable fruits produced by 'Sakura' were not significantly different from either 'Favorita' or 'BHN 268' (Table 1). During the second-year field experiment, Sakura and BHN 268 had significantly greater marketable yield among the cherry tomato cultivars (Table 1). The average weekly harvest yield was also greater for 'BHN 268' and 'Sakura' than 'Favorita' for the first six weeks of production in 2019 (Fig. 1A). However, the trend of marketable fruit numbers was opposite to marketable fruit weight as the number of marketable fruits produced by 'Favorita' were significantly greater than that produced by 'BHN 268' and 'Sakura' (Table 1).

For slicer tomato cultivars, the greatest marketable yield was reported from Geronimo, which was significantly greater than marketable yield produced by Trust during the first-year experiment. The marketable yield of 'BHN 964' was not significantly different from either 'Geronimo' or 'Trust' (Table 1). The number of marketable fruits produced by 'Geronimo' were significantly greater than that produced by both 'BHN 964' and 'Trust' individually. For the second-year experiment, 'Geronimo' produced significantly greater marketable yield as compared with 'BHN 964' and 'Trust' (Table 1). The average weekly harvest yield results also showed that 'Geronimo' had greater average weekly yield compared with 'BHN 964' and 'Trust' during the last 7 weeks of production, while there was not significant difference among all three slicer tomato cultivars for weekly production during the first 6 weeks of production (Fig. 1B). The number of marketable fruits produced during the second year were significantly greater for 'Geronimo' and 'Trust' compared with that produced from 'BHN 964' (Table 1).

Greenhouse production. During the first year, there was no significant difference for the marketable yield among different cherry tomato cultivars, while Favorita and Sakura produced significantly greater number of marketable fruits as compared with BHN 268 (Table 2). In the second year, 'Sakura' had significantly greater marketable yield than that produced by 'Favorita' and 'BHN 268', whereas marketable yield produced by 'Favorita' was significantly greater than that of 'BHN 268' (Table 2). During the second year, the number of marketable fruits produced by Favorita and Sakura were also significantly greater among cherry tomato cultivars in the secondyear experiment as observed during the first

Table 1. Yield data for tomatoes grown under field conditions at the Botanic Garden, Stillwater, OK.

\begin{tabular}{lcccccc}
\hline & $\begin{array}{c}\text { No. of } \\
\text { marketable } \\
\text { fruits }\end{array}$ & $\begin{array}{c}\text { Wt marketable } \\
\text { yield (kg/plant) }\end{array}$ & $\begin{array}{c}\text { Avg } \\
\text { size (g) }\end{array}$ & $\begin{array}{c}\text { No. of } \\
\text { marketable } \\
\text { fruits }\end{array}$ & $\begin{array}{c}\text { Wt marketable } \\
\text { yield (kg/plant) }\end{array}$ & $\begin{array}{c}\text { Avg } \\
\text { size (g) }\end{array}$ \\
\hline \multicolumn{3}{c}{ Yr 2019 (cherry) } & & & Yr 2020 (cherry) \\
\hline BHN 268 & $194 \mathrm{~b}^{\mathrm{z}}$ & $3.28 \mathrm{a}$ & $17.88 \mathrm{a}$ & $312 \mathrm{c}$ & $6.11 \mathrm{a}$ & $27.39 \mathrm{a}$ \\
Favorita & $382 \mathrm{a}$ & $2.62 \mathrm{a}$ & $6.66 \mathrm{c}$ & $721 \mathrm{a}$ & $4.95 \mathrm{~b}$ & $8.39 \mathrm{~b}$ \\
Sakura & $272 \mathrm{ab}$ & $2.27 \mathrm{a}$ & $11.52 \mathrm{~b}$ & $487 \mathrm{~b}$ & $5.93 \mathrm{a}$ & $13.41 \mathrm{ab}$ \\
\hline \multicolumn{7}{c}{ Yr 2019 (slicer) } \\
\hline BHN 964 & $15 \mathrm{~b}$ & $2.75 \mathrm{ab}$ & $136.55 \mathrm{a}$ & $19 \mathrm{~b}$ & $4.19 \mathrm{~b}$ & $173.11 \mathrm{a}$ \\
Geronimo & $31 \mathrm{a}$ & $3.60 \mathrm{a}$ & $91.81 \mathrm{ab}$ & $39 \mathrm{a}$ & $6.18 \mathrm{a}$ & $145.76 \mathrm{ab}$ \\
Trust & $15 \mathrm{~b}$ & $1.41 \mathrm{~b}$ & $73.82 \mathrm{~b}$ & $33 \mathrm{a}$ & $3.90 \mathrm{~b}$ & $119.60 \mathrm{~b}$ \\
\hline
\end{tabular}

${ }_{\mathrm{z}}$ Means $(\mathrm{n}=10)$ within a column and fruit type followed by the same letter are not significantly different based on least significant difference test at $P \leq 0.05$. year. The same trend was seen in the average weekly harvest yield results throughout the harvesting season (Fig. 1C). Additionally, the average weekly harvest yield of 'Sakura' was greater than 'Favorita' for the first 4 weeks only, whereas for the later weeks, the average weekly yield of both 'Favorita' and 'Sakura' was not different (Fig. 1C).

In the first year, there was no significant difference among slicer tomato cultivars for marketable yield and number of marketable fruits (Table 2). However, during the second year, there was significant cultivar effect on the marketable yield of slicer tomatoes. The marketable fruit weight and number produced by 'BHN 964' was significantly greater compared with that produced by 'Geronimo' and 'Trust' (Table 2). The average weekly harvest yield also showed that BHN 964 had greater weekly yield for the first 6 weeks, whereas later there was no difference among different slicer tomato cultivars (Fig. 1D).

Average fruit size. For field production, the average cherry tomato fruit size was greater for 'BHN 268' compared with that of 'Sakura' and 'Favorita' on all harvest dates except the first and last week (Fig. 2A). Thus, the average cherry tomato fruit size was significantly greater for 'BHN 268' than for 'Sakura' and 'Favorita' for both years (Table 1). Average cherry tomato fruit size for 'Sakura' was significantly greater than 'Favorita' during the first year but not the second year (Table 1). These results were also supported by the average cherry tomato fruit size for 'Sakura' being greater than 'Favorita' on all sampling dates except the last week (Fig. 2A). For slicer tomatoes, 'BHN 964' had significantly greater fruit size compared with 'Trust', whereas average fruit size of 'Geronimo' was not different from 'BHN 964' or from 'Trust' during either year (Table 1). These results were also supported by the dynamics showing that average slicer tomato fruit size for 'BHN 964' remained greater throughout the harvesting period followed by 'Trust' and 'Geronimo' (Fig. 2B).

For greenhouse production, there was no significant difference among different cherry tomato cultivars for average fruit size during year 1 , but in year 2 , the average fruit size for Sakura was significantly greater than Favorita and followed by BHN 268 (Table 2). These results were also supported by the dynamics of average cherry tomato fruit size showing that average size for 'Sakura' was greater than 'Favorita' and 'BHN 268' on all harvesting dates except weeks 3, 4, 5, and 6 (Fig. 2C). For slicer tomatoes, average fruit size was not significantly different during year 1 , whereas for year 2, average fruit size for 'BHN 964' was significantly greater than that of 'Geronimo' and 'Trust' (Table 2). Supporting these results, the dynamics of average slicer tomato size also demonstrated that average fruit size of $\mathrm{BHN}$ 964 was greater than the other two cultivars on all harvesting dates except four, whereas average size of the other two cultivars remained similar throughout the harvesting period (Fig. 2D).

Taste. Using the ratings provided by the individuals, the average rating was calculated. 

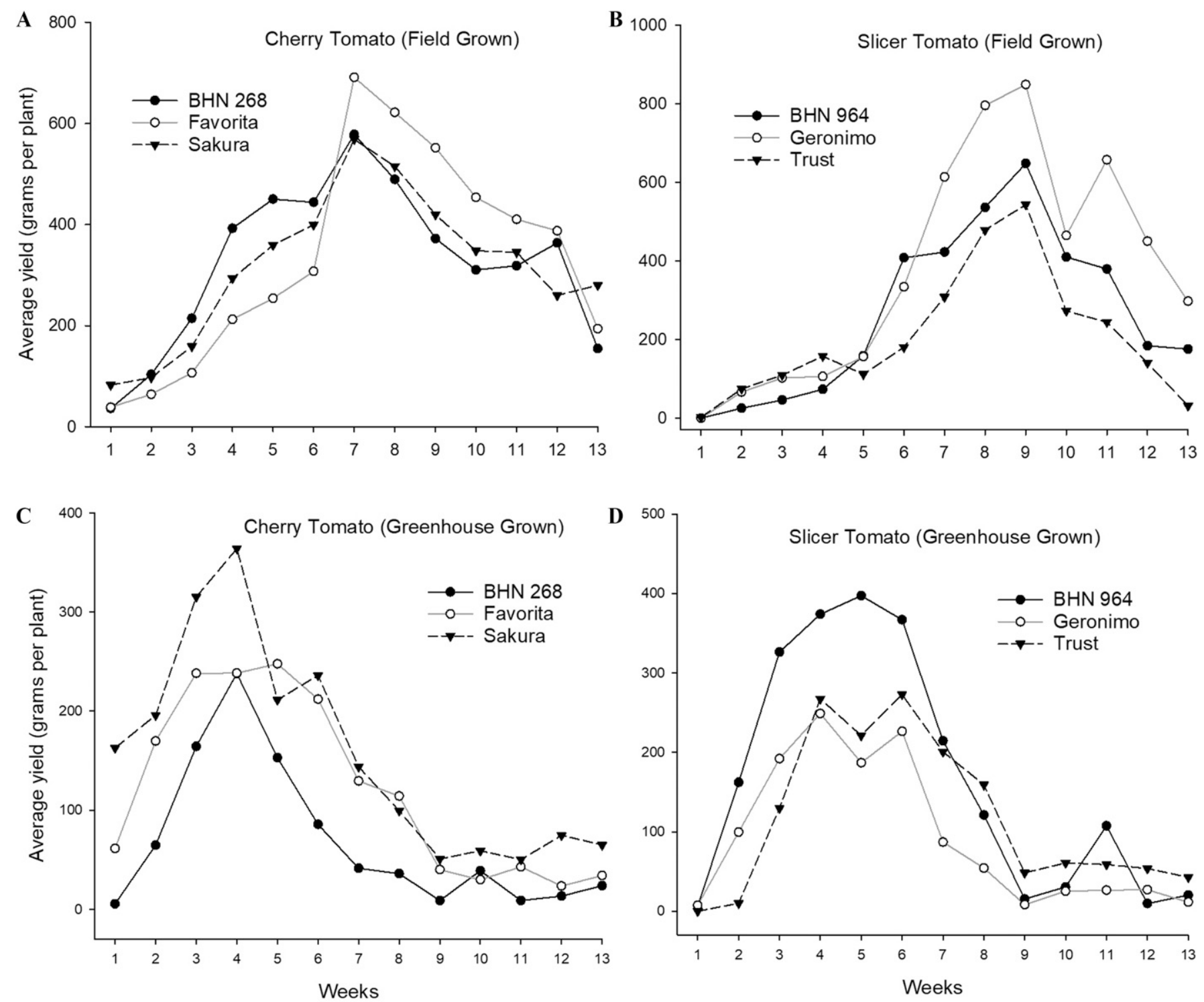

Fig. 1. Average weekly harvest yield overtime of cherry and slicer tomato cultivars cultivated in the field (Perkins, OK) and grown in Dutch buckets in a greenhouse (Stillwater, OK) in 2019.

There was no interaction between production system and cultivars of different types of tomatoes. The main effect of production system was significant for taste of tomatoes, whereas the main effect of cultivars was not significant. Taste ratings of tomatoes from the field production was significantly greater than ratings for the tomatoes produced from greenhouse (Fig. 3).

Lycopene content. Only most ripe tomato fruits were used for analyzing lycopene content. The lycopene content was measured as micrograms per gram of fruit and micrograms per fruit. For slicer tomato cultivars, there
Table 2. Yield data for tomatoes grown in Dutch buckets under greenhouse conditions in Stillwater, $\mathrm{OK}$.

\begin{tabular}{lcccccr}
\hline & $\begin{array}{c}\text { No. of } \\
\text { marketable } \\
\text { fruits }\end{array}$ & $\begin{array}{c}\text { Wt marketable } \\
\text { yield (kg/plant) }\end{array}$ & $\begin{array}{c}\text { Avg } \\
\text { size (g) }\end{array}$ & $\begin{array}{c}\text { No. of } \\
\text { marketable } \\
\text { fruits }\end{array}$ & $\begin{array}{c}\text { Wt marketable } \\
\text { yield (kg/plant) }\end{array}$ & $\begin{array}{c}\text { Avg } \\
\text { size (g) }\end{array}$ \\
\hline BHN 268 & $78 \mathrm{~b}^{\mathrm{z}}$ & Yr 2019 (cherry) & & & Yr 2020 (cherry) & \\
Favorita & $158 \mathrm{a}$ & $1.45 \mathrm{a}$ & $12.52 \mathrm{a}$ & $46 \mathrm{~b}$ & $0.44 \mathrm{c}$ & $5.98 \mathrm{c}$ \\
Sakura & $166 \mathrm{a}$ & $1.72 \mathrm{a}$ & $10.76 \mathrm{a}$ & $172 \mathrm{a}$ & $1.71 \mathrm{~b}$ & $8.05 \mathrm{~b}$ \\
\hline & & Yr 2019 (slicer) & & & Yr 2020 (slicer) & \\
\hline BHN 964 & $27 \mathrm{a}$ & $2.04 \mathrm{a}$ & $53.05 \mathrm{a}$ & $21 \mathrm{a}$ & $2.27 \mathrm{a}$ & $49.84 \mathrm{a}$ \\
Geronimo & $19 \mathrm{a}$ & $1.66 \mathrm{a}$ & $41.78 \mathrm{a}$ & $8 \mathrm{~b}$ & $0.75 \mathrm{~b}$ & $28.54 \mathrm{~b}$ \\
Trust & $42 \mathrm{a}$ & $1.83 \mathrm{a}$ & $44.12 \mathrm{a}$ & $18 \mathrm{ab}$ & $1.22 \mathrm{~b}$ & $32.32 \mathrm{~b}$ \\
\hline
\end{tabular}

${ }^{\mathrm{z}}$ Means $(\mathrm{n}=18)$ within a column followed by the same letter are not significantly different based on least significant difference test at $P \leq 0.05$. was a four-way interaction (year $\times$ production system $\times$ cultivar $\times$ harvest season) for lycopene content both as micrograms per gram of fruit and micrograms per fruit, so values are compared across years, production systems, cultivars, and harvesting season individually for micrograms per gram of fruit then micrograms per fruit. The lycopene content ranged between 35.77 to $85.02 \mu \mathrm{g}$ per $\mathrm{g}$ of fruit and 1394.71 to $14,821.00 \mu \mathrm{g}$ per fruit. In 2019, BHN 964 had significantly greater lycopene content as micrograms per gram of fruit as compared with the other two slicer tomato cultivars under field conditions (Table 3). Results under greenhouse conditions indicated that Trust had significantly greater lycopene content as micrograms per gram of fruit compared with other two cultivars except for late season fruits where it was greater for Geronimo. In 2020, 'Trust' had significantly greater lycopene content as micrograms per gram of fruit for midseason fruits, while lycopene content was not significantly different between 'Trust' and 'BHN 964' under both field and 

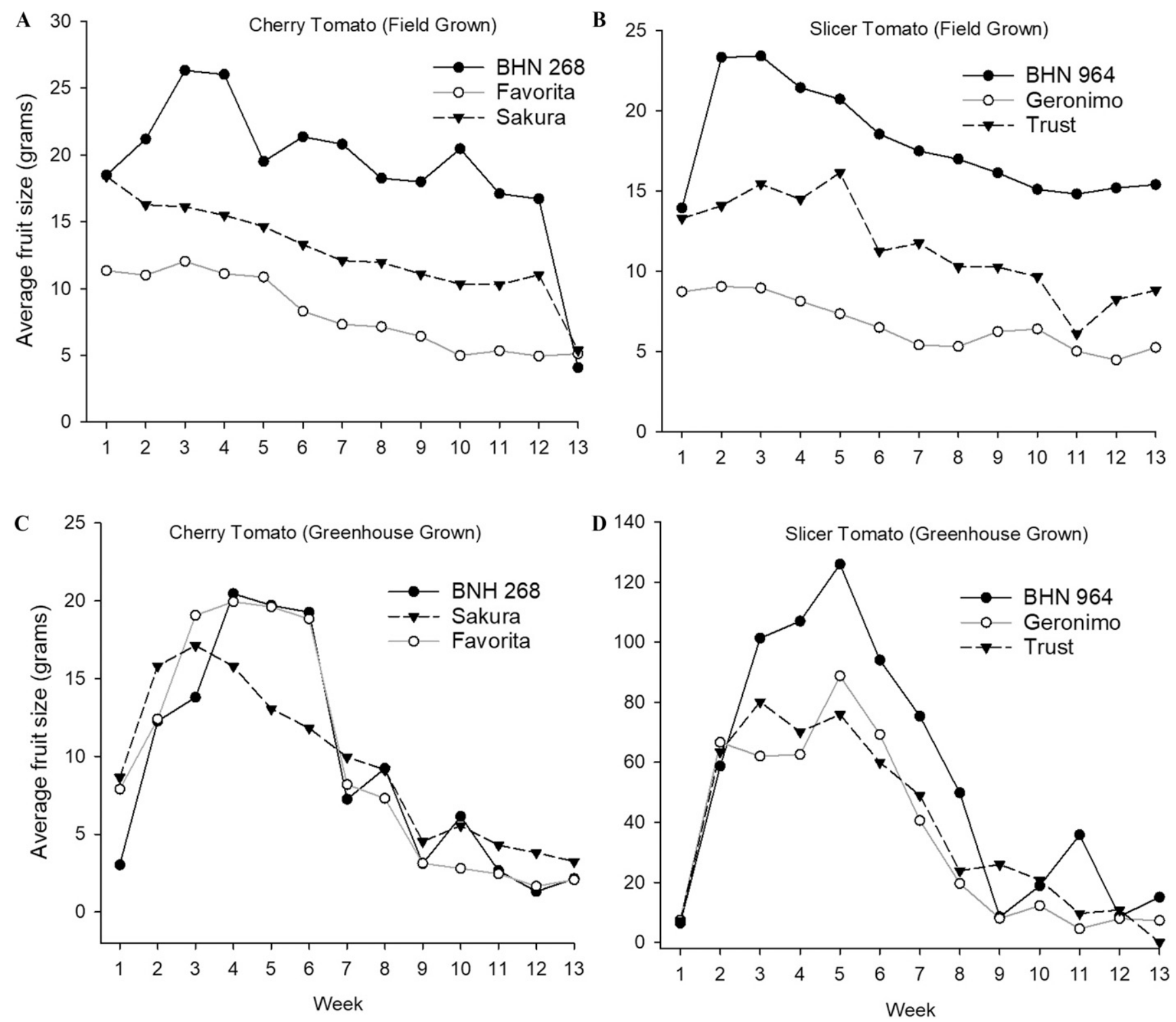

Fig. 2. Average fruit size overtime of cherry and slicer tomato cultivars cultivated in the field (Perkins, OK) and grown in Dutch buckets in the greenhouse (Stillwater, OK) in 2020.

greenhouse conditions (Table 3). Results for lycopene content as micrograms per fruit followed different trends, where it was

significantly greater for BHN 964 compared with the other two cultivars in 2019 under field conditions, and under greenhouse conditions,

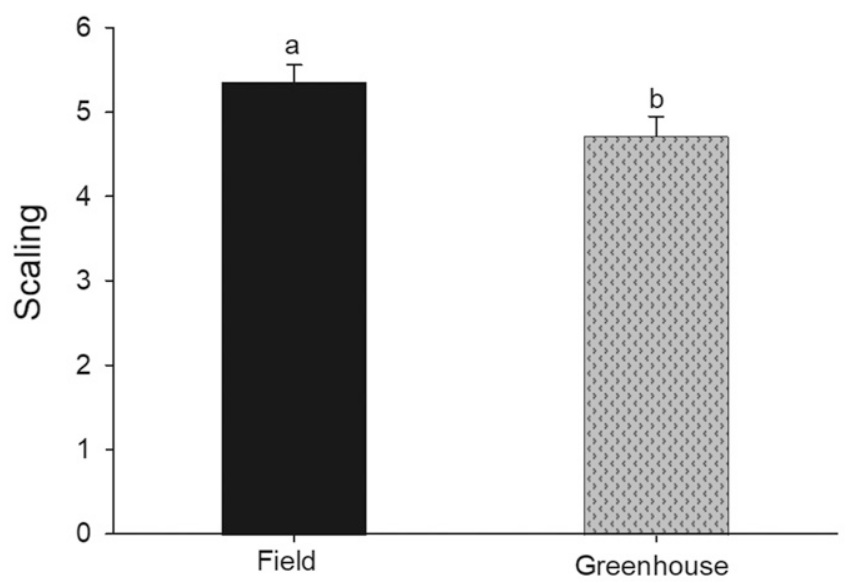

Fig. 3. Main effect of cropping system on tomato taste. Bars marked with the same letter are not significantly different from each other according to least significant difference test at $P<0.05$.
'Geronimo' had significantly greater lycopene content as micrograms per fruit except for midseason fruits (Table 3). During 2020, 'Trust' had significantly greater lycopene content as micrograms per fruit except for lateseason fruits under field conditions, whereas for greenhouse conditions 'BHN 964', 'Trust', and 'Geronimo' had significantly greater lycopene content as micrograms per fruit except for early-, mid-, and late-season fruits, respectively (Table 3 ).

For cherry tomato cultivars, there was also a four-way interaction (year $\times$ production system $\times$ cultivar $\times$ harvest season) for lycopene content. The lycopene content ranged between 31.94 to $114.36 \mu \mathrm{g}$ per $\mathrm{g}$ of fruit and 1449.20 to $186.84 \mu \mathrm{g}$ per fruit. The lycopene content as micrograms per gram of fruit was lowest on early season fruits and higher in late-season fruits with some exceptions such as lycopene content for 'Favorita' and 'BHN 268' under greenhouse conditions 
Table 3. Four-way interaction of year, production system (field and greenhouse), cultivars of slicer tomato (Geronimo, Trust, and BHN 964), and harvesting season (early, mid, and late) for lycopene content of most ripe fruits for micrograms per gram of fruit and micrograms per fruit analyzed individually.

\begin{tabular}{|c|c|c|c|c|c|c|c|}
\hline \multirow[b]{2}{*}{ Yr } & \multicolumn{4}{|c|}{ Field } & \multicolumn{3}{|c|}{ Greenhouse } \\
\hline & Cultivar & Early-season & Mid-season & Late-season & Early-season & Mid-season & Late-season \\
\hline & \multicolumn{7}{|c|}{$\mu \mathrm{g}$ per $\mathrm{g}$ of fruit } \\
\hline \multirow[t]{3}{*}{2019} & Geronimo & $59.46 \mathrm{hi}^{\mathrm{z}}$ & $50.21 \mathrm{~m}$ & $47.52 \mathrm{no}$ & $37.12 \mathrm{t}$ & $57.13 \mathrm{jk}$ & $70.87 \mathrm{~d}$ \\
\hline & Trust & $42.98 \mathrm{i}$ & 46.63 op & $58.63 \mathrm{ij}$ & $48.73 \mathrm{mn}$ & $81.82 \mathrm{~b}$ & 53.531 \\
\hline & BHN 964 & $58.09 \mathrm{ij}$ & $55.97 \mathrm{k}$ & $66.17 \mathrm{e}$ & $37.08 \mathrm{t}$ & $76.74 \mathrm{c}$ & $58.74 \mathrm{ij}$ \\
\hline \multirow[t]{4}{*}{2020} & Geronimo & $40.96 \mathrm{~s}$ & $42.37 \mathrm{rs}$ & $45.34 \mathrm{pq}$ & $35.77 \mathrm{t}$ & $57.17 \mathrm{jk}$ & $61.20 \mathrm{gh}$ \\
\hline & Trust & $63.34 \mathrm{f}$ & $80.80 \mathrm{~b}$ & $48.81 \mathrm{mn}$ & $44.15 \mathrm{qr}$ & $85.02 \mathrm{a}$ & $64.22 \mathrm{ef}$ \\
\hline & BHN 964 & $62.85 \mathrm{fg}$ & $59.43 \mathrm{hi}$ & $57.41 \mathrm{i}-\mathrm{k}$ & $45.45 \mathrm{pq}$ & 53.791 & 48.03 no \\
\hline & \multicolumn{7}{|c|}{$\mu \mathrm{g}$ per fruit } \\
\hline \multirow[t]{3}{*}{2019} & Geronimo & $7657.20 \mathrm{i}^{\mathrm{y}}$ & 4831.53 op & $4784.37 \mathrm{p}$ & 9809.58 ef & $2769.80 \mathrm{uv}$ & $3156.06 \mathrm{st}$ \\
\hline & Trust & 6659.301 & 5088.70 no & $4195.28 \mathrm{q}$ & $7549.07 \mathrm{i}$ & $2061.45 \mathrm{w}$ & $1394.71 \mathrm{x}$ \\
\hline & BHN 964 & $10,075.00 \mathrm{e}$ & $7712.40 \mathrm{i}$ & $11,864.00 \mathrm{c}$ & $6972.14 \mathrm{k}$ & $2818.21 \mathrm{uv}$ & $2591.96 \mathrm{v}$ \\
\hline \multirow[t]{3}{*}{2020} & Geronimo & $8246.13 \mathrm{~h}$ & $10,985.00 \mathrm{~d}$ & $5270.16 \mathrm{n}$ & $2985.37 \mathrm{tu}$ & $7245.78 \mathrm{jk}$ & $8198.02 \mathrm{~h}$ \\
\hline & Trust & $9546.55 \mathrm{fg}$ & $14,294.00 \mathrm{~b}$ & $3299.18 \mathrm{~s}$ & $2775.85 \mathrm{uv}$ & $9282.74 \mathrm{~g}$ & $7484.13 \mathrm{ij}$ \\
\hline & BHN 964 & $7446.02 \mathrm{ij}$ & $14,821.00 \mathrm{a}$ & 4898.68 ор & $3655.15 \mathrm{r}$ & $7666.22 \mathrm{i}$ & $6254.33 \mathrm{~m}$ \\
\hline
\end{tabular}

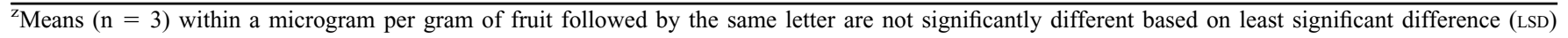
test at $P \leq 0.05$.

${ }^{\mathrm{y}}$ Means $(\mathrm{n}=3)$ within a microgram per fruit followed by the same letter are not significantly different based on LSD test at $P \leq 0.05$.

was significantly greater in midseason fruits as compared with late-season fruits in 2019 (Table 4). For all cherry tomato cultivars, the lycopene content as micrograms per gram of fruit was significantly greater in greenhouse conditions compared with that in field conditions except cultivar BHN 268 where lycopene content as micrograms per gram of fruit was greater under field conditions compared with that under greenhouse conditions in early- and late-season fruits in 2019 and only early season fruits in 2020 (Table 4). Comparing among cultivars, lycopene content as micrograms per gram of fruit was mostly significantly greater for Sakura (Table 4). Lycopene content as micrograms per gram of fruit had different trends where it decreased over the harvest season in field conditions and increased with increasing over the harvest season under greenhouse conditions.

\section{Discussion}

Greenhouse tomato production has been reported to benefit growers by procuring premium prices for their produce by targeting the early market demands especially in temperate regions. This is mainly because greenhouses provide protection from low temperatures and early accumulation of growing degree days advancing crop harvest by 3 to 4 weeks (O'Connell et al., 2012). The results from our current study also showed that greenhouse tomato production was able to produce fruits nearly 4 to 6 weeks earlier than field production. However, greenhouse tomato production is reported to be more expensive than field production due to costs associated with building infrastructure. The higher costs of greenhouse production can be offset by the ability to obtain greater profits due to higher yields and targeting of early markets. Additionally, the level of greenhouse tomato production was more consistent in both years, whereas the field production of tomatoes was highly variable between both years with greater yields in the second year. This suggests reduced yield variability with greenhouse production compared with the field production system. Previous studies also reported more consistent tomato yields when produced under protected cultivation systems (Nordey et al., 2017; O'Connell et al., 2012).

Cultivar selection for different production systems is important because cultivars designed for field production do not do well in greenhouse conditions (Peet and Welles, 2005). Differences among cultivars in growth habit, disease resistance, and a host of other traits mean that growers must make decisions based on their willingness to accept tradeoffs in performance traits between cultivars. Previous studies reported that Geronimo and Trust are the most popular slicer tomato cultivars for protected cultivation system due to their different traits such as consistency in year-to-year yield, high yield, and resistance to some diseases (Thaxton and Hochmuth, 2015; Warren et al., 2015). However, results from the current experiments showed that 'BHN 964' produced significantly greater yields than 'Geronimo' and 'Trust' in both greenhouse and field conditions. Although data for resistance to diseases was not taken during the current experiment, there is a need to conduct studies related to disease resistance for these cultivars under different

Table 4. Four-way interaction of year, production system (field and greenhouse), cultivars of cherry tomato (Favorita, Sakura, and BHN 268), and harvesting season (early, mid, and late) for lycopene content of most ripe fruits for micrograms per gram of fruit and micrograms per fruit analyzed individually.

\begin{tabular}{|c|c|c|c|c|c|c|c|}
\hline \multirow[b]{2}{*}{$\mathrm{Yr}$} & \multirow[b]{2}{*}{ Cultivar } & \multicolumn{3}{|c|}{ Field } & \multicolumn{3}{|c|}{ Greenhouse } \\
\hline & & Early-season & Mid-season & Late-season & Early season & Mid season & Late season \\
\hline & \multicolumn{7}{|c|}{$\mu \mathrm{g}$ per $\mathrm{g}$ of fruit } \\
\hline \multirow{2}{*}{2019} & Sakura & $47.33 \mathrm{su}$ & $67.85 \mathrm{~h}-\mathrm{i}$ & $71.56 \mathrm{~g}$ & $55.64 \mathrm{n}$ & $63.52 \mathrm{k}-\mathrm{m}$ & $85.45 \mathrm{c}$ \\
\hline & BHN 268 & $44.41 \mathrm{uv}$ & $41.43 \mathrm{v}$ & $67.81 \mathrm{hi}$ & $31.94 \mathrm{x}$ & $114.36 \mathrm{a}$ & 54.58 no \\
\hline \multirow[t]{2}{*}{2020} & Favorita & $49.36 \mathrm{q}-\mathrm{s}$ & $60.48 \mathrm{~m}$ & $69.86 \mathrm{gh}$ & $48.93 \mathrm{r}-\mathrm{t}$ & $77.85 \mathrm{f}$ & $78.97 \mathrm{ef}$ \\
\hline & Sakura & 51.38 p-r & $54.30 \mathrm{n}-\mathrm{p}$ & $66.02 \mathrm{i}-\mathrm{k}$ & 51.65 o-r & $84.05 \mathrm{~cd}$ & $92.80 \mathrm{~b}$ \\
\hline \multirow[t]{3}{*}{2019} & Favorita & $367.17 \mathrm{u}^{\mathrm{y}}$ & $318.29 \mathrm{w}$ & $323.42 \mathrm{vw}$ & $186.84 \mathrm{x}$ & $376.19 \mathrm{u}$ & $361.29 \mathrm{uv}$ \\
\hline & Sakura & $722.14 \mathrm{j}$ & $829.10 \mathrm{~h}$ & $600.27 \mathrm{ml}$ & $579.61 \mathrm{mn}$ & $371.27 \mathrm{u}$ & 544.03 no \\
\hline & BHN 268 & $1075.29 \mathrm{e}$ & $679.27 \mathrm{k}$ & $1074.45 \mathrm{e}$ & 533.64 op & $920.91 \mathrm{~g}$ & $431.89 \mathrm{rs}$ \\
\hline \multirow[t]{3}{*}{2020} & Favorita & $499.56 \mathrm{pq}$ & $461.13 \mathrm{qr}$ & $418.37 \mathrm{st}$ & $367.85 \mathrm{u}$ & $946.43 \mathrm{~g}$ & $914.65 \mathrm{~g}$ \\
\hline & Sakura & $784.75 \mathrm{i}$ & $711.29 \mathrm{jk}$ & $816.49 \mathrm{ih}$ & 624.531 & $1294.53 \mathrm{~b}$ & $1319.52 \mathrm{~b}$ \\
\hline & BHN 268 & $1118.49 \mathrm{~d}$ & $1186.02 \mathrm{c}$ & $986.35 \mathrm{f}$ & 389.47 tu & $1065.93 \mathrm{e}$ & $1449.20 \mathrm{a}$ \\
\hline
\end{tabular}

${ }^{\mathrm{z}}$ Means $(\mathrm{n}=3)$ within a microgram per gram of fruit followed by the same letter are not significantly different based on least significant difference (LSD) test at $P \leq 0.05$.

${ }^{\mathrm{y}}$ Means $(\mathrm{n}=3)$ within a microgram per fruit followed by the same letter are not significantly different based on LSD test at $P \leq 0.05$. 
growing systems. Similarly, Favorita and Sakura are highly recommended cherry tomato cultivars due to their high yielding characteristic (Pickens et al., 2020; Radin, 2016). However, 'BHN 268' is also highly recommended among cherry tomatoes in Florida due to its greater shelf life and resistance to verticillium wilt (race 1) and fusarium wilt (race 1) (Freeman et al., 2014; Olson et al., 2006). The results from current experiment also validated the greater yield of 'BHN 268' than 'Favorita' and 'Sakura' for field production. While for greenhouse production, BHN 268 had greater yield only during the first year and had lower yield compared with Sakura, which had a significantly greater yield among all cherry tomato cultivars in the second year. Yield variability within greenhouse tomato production is well understood to be influenced by environmental (light, temperature, carbon dioxide) levels, production management related to nutrition, disease, and insect control; as well as pruning and harvesting practices (Heuvelink and Dorais, 2005). In addition, yield variability among field tomato production is also heavily influenced by weeds and plant water status (Clark et al., 1999).

Compared with the remarkable achievement in increasing yield and market acceptance of greenhouse tomato, it seems that improving organoleptic and/or nutritional quality of the fruit has received less emphasis in North American greenhouse industries (Kubota et al., 2012). Overall flavor of tomato fruit is commonly evaluated using total soluble sugars (TSS) estimated using a refraction index (Brix) as an indicator. Sugar and organic acids are important flavor components in tomato fruit and measurements of refraction index are affected predominantly by sugars and by organic acids (Saltveit, 2005). Therefore, previous studies evaluating taste of tomato used TSS as the best indicator and generally accepting that tomato fruit with greater TSS is more flavorful. However, in the current study actual taste test using individuals was conducted instead of measuring TSS under laboratory conditions because flavor and nutritional quality are considered as "experience-based quality attributes" (Wismer, 2014). As TSS concentration is affected by water content in fruit, it is assumed that tomatoes produced under hydroponic systems in greenhouse have higher water content and lower TSS concentration due to negative correlation between water potential and fruit TSS (Kubota et al., 2012). In contrast to this, tomato produced in field conditions are produced under lower (more negative) water potential in the root zone compared with hydroponic production, thereby resulting in fruits with greater TSS concentration (Buck et al., 2008; Yeshiwas and Tolessa, 2018).

The results from the current experiment for taste analysis of tomatoes from different production systems supported the results from previous studies (Dzakovich et al., 2016). The individuals rated the open field-produced tomatoes significantly better for taste compared with greenhouse-produced tomatoes. A possible reason for this can be the difference in TSS concentration of tomatoes produced under different production systems. It would have possibly been better explained if additional TSS concentration would have been recorded in tandem with taste analysis.

Another important factor that determines acceptability of tomato by customers is tomato color, which is mainly regulated by the amount of lycopene content present in tomato fruits (Dávila-Aviña et al., 2011). Additionally, lycopene is a major dietary carotenoid present on tomato fruit, which protects cells against oxidative damage to lipids, proteins, and DNA (Cheng et al., 2019). Lycopene content is influenced by several factors, such as agricultural practices (greenhouse, open field, varieties, water supply, fertilization), soil, climate factors (temperature, moisture, solar radiation), fruit growth, harvesting date, degree of maturity, and postharvest handling (Brandt et al., 2003). The results from the current study also showed an interaction effect of years (effect of different climatic factors), different cultivars, harvest time (early, mid, and late season), and production systems (open field and greenhouse) on lycopene content of cherry and slicer tomatoes. In most cases, lycopene content (micrograms per gram of fruit) was greater under greenhouse conditions compared with open field production for mid- and late-season fruits. These results are also supported by the results from Brandt et al. (2003) which reported significantly greater lycopene content from tomatoes produced under greenhouse conditions compared with field conditions. The possible explanation for this may be controlled temperature under greenhouse conditions as lycopene production is reported to be sensitive to temperature being inhibited above $32^{\circ} \mathrm{C}$ (Farkas, 1994). Specifically, Setyorini (2021) reported that respiration is increased under high temperatures, which leads to a degradation of lycopene into terpenes. The mid- and late-season tomatoes were harvested in July and August, when the average temperature in Oklahoma is $\approx 34^{\circ} \mathrm{C}$ (Singh et al., 2019), which may have affected lycopene production in open field-produced tomatoes but not for those produced under shaded greenhouse conditions.

\section{Conclusion}

It can be concluded that BHN 964 and Geronimo produced greater yield among slicer tomato cultivars for greenhouse and open field production, respectively. The average fruit size of BHN 964 was significantly greater than the other two cultivars under greenhouse conditions, whereas under field conditions, average fruit size for BHN 964 and Geronimo was similar. Among cherry tomato cultivars, BHN 268 was the highest producer for open field production and Sakura for greenhouse production conditions. Among slicer tomato cultivars, average fruit size of BHN 964 was significantly greater than other two cultivars under greenhouse conditions, whereas under field conditions, average fruit size for BHN 964 and Geronimo was similar. Among cherry tomato cultivars, BHN 268 and Sakura had greater sized fruits compared with that of Favorita. The field produced tomatoes were rated higher for taste as compared with that produced under greenhouse conditions. However, the mid and late-season cherry and slicer tomato fruits produced under field conditions had lower lycopene content compared with greenhouse-produced tomato fruits. Therefore, careful selection of tomato cultivars is important for different production systems. Future research should investigate production of other tomato cultivars under different production systems with similar experimental designs so yield could be compared among production systems. Also, TSS concentration of tomato fruits should be analyzed in tandem with human taste analysis to know how strongly these are both correlated.

\section{Literature Cited}

Brandt, S., A. Lugasi, É. Barna, Z.J. Hóvári, Z. Pék, and L. Helyes. 2003. Effects of the growing methods and conditions on the lycopene content of tomato fruits. Acta Aliment. 32(3): 269-278, doi: 10.1556/aalim.32.2003.3.6.

Buck, J.S., C. Kubota, and M. Jensen. 2008. Effect of mid-day reduction of high electrical conductivity treatment on the yield and quality of greenhouse cherry tomato. HortTechnology 18(3): 460-466, doi: 10.21273/HORTTECH.18.3.460.

Cheng, H.M., G. Koutsidis, J.K. Lodge, A.W. Ashor, M. Siervo, and J. Lara. 2019. Lycopene and tomato and risk of cardiovascular diseases: A systematic review and meta-analysis of epidemiological evidence. Crit. Rev. Food Sci. Nutr. 59:141-158, doi: 10.1080/10408398.2017.1362630.

Clark, M.S., W.R. Horwath, C. Shennan, K.M. Scow, W.T. Lantni, and H. Ferris. 1999. Nitrogen, weeds and water as yield-limiting factors in conventional, low-input, and organic tomato systems. Agr. Ecosyst. Environ. 73:257-270, doi: 10.1016/S0167-8809(99)00057-2.

Cook, R. and L. Calvin. 2005. Greenhouse tomatoes change the dynamics of the North American fresh tomato industry. U.S. Department of Agriculture, Economic Research Service. USDA Economic Research Report No. 2.

Cornell University. 2018. Vegetables 2018 Summary. 7 Jan. 2021. <https://downloads.usda. library.cornell.edu/usda-esmis/files/02870v86p/ gm80j322z/5138jn50j/vegean19.pdf>.

Csizinsky, A.A. 2005. Production in the open field, p. 237-256. In: E. Heuvelink (ed.). Tomatoes. CABI, Wallingford, UK, doi: 10.1079/978085 1993966.0237.

Dávila-Aviña, J.E.J., J. Villa-Rodríguez, R. CruzValenzuela, M. Rodríguez-Armenta, M Espino-Díaz, J.F. Ayala-Zavala, G.I. OlivasOrozco, B. Heredia, and G. González-Aguilar. 2011. Effect of edible coatings, storage time and maturity stage on overall quality of tomato fruits. Amer. J. Agr. Biol. Sci. 6(1):162-171, doi: 10.3844/ajabssp.2011.162.171.

Dzakovich, M.P., M.G. Ferruzzi, and C.A. Mitchell. 2016. Manipulating sensory and phytochemical profiles of greenhouse tomatoes using environmentally relevant doses of ultraviolet radiation. J. Agr. Food Chem. 64(36):68016808, doi: 10.1021/acs.jafc.6b02983.

Farkas, J. 1994. Tomato, p. 195-226. In: S. Balazs (ed.). Handbook of Vegetable Growers. Mezogazda Kiado, Budapest.

Figàs, M.R., J. Prohens, M.D. Raigón, L. PereiraDias, C. Casanova, M.D. García-Martínez, E. 
Rosa, E. Soler, M. Plazas, and S. Soler. 2018. Insights into the adaptation to greenhouse cultivation of the traditional Mediterranean long shelf-life tomato carrying the alc mutation: A multi-trait comparison of landraces, selections, and hybrids in open field and greenhouse. Front. Plant Sci. 9:1774, doi: 10.3389/ fpls.2018.01774.

Freeman, J.H., E.J. McAvoy, N. Boyd, P.J. Dittmar, M. Ozores-Hampton, H.A. Smith, G.E. Vallad, and S.E. Webb. 2014. Tomato production, p. 183-204. In: G.E. Vallad, J.H. Freeman, and P.J. Dittmar (eds.). Vegetable Production Handbook for Florida, doi: 10.32473/edis-cv137-2020.

Guan, Z., T. Biswas, and W. Feng. 2017. The US tomato industry: An overview of production and trade. 14 May 2021. < https://edis.ifas.ufl. edu/fe $1027 \geq$.

Heuvelink, E. and M. Dorais. 2005. Crop growth and yield, p. 85-144. In: Tomatoes, doi: 10.1079/9780851993966.0085.

Jensen, M.H. 1997. Hydroponics worldwide, p. 719-730. In: International Symposium on Growing Media and Hydroponics 481, doi: 10.17660/ActaHortic.1999.481.87.

Jones, J.B., Jr. 2008. Tomato plant culture: In the field, greenhouse, and home garden. CRC Press, New York, NY, doi: 10.1201/9781003041078.

Kubota, C., M. Kroggel, M. Torabi, K.A. Dietrich, H.-J. Kim, C.A. Thomson. 2012. Changes in selected quality attributes of greenhouse tomato fruit as affected by pre- and postharvest environmental conditions in year-round production.HortScience 47:1698-1704, doi: 10.21273/ HORTSCI.47.12.1698.

Morgan, L. 2003. Hydroponic tomatoes. The Growing Edge. 14(6). 14 May 2021. <http://gpnmag. com/wp-content/uploads/p78\%20Morgan.pdf $>$.

Nordey, T., C. Basset-Mens, H. De Bon, T. Martin, E. Déletré, S. Simon, L. Parrot, H. Despretz, J. Huat, Y. Biard, and T. Dubois. 2017. Protected cultivation of vegetable crops in sub-Saharan Africa: Limits and prospects for smallholders. A review. Agron. Sustain. Dev. 37(6):53, doi: 10.1007/s13593-017-0460-8.

O'Connell, S., C. Rivard, M.M. Peet, C. Harlow, and F. Louws. 2012. High tunnel and field production of organic heirloom tomatoes: Yield, fruit quality, disease, and microclimate. HortScience 47(9): 1283-1290, doi: 10.21273/hortsci.47.9.1283.

Olson, S.M., W.M. Stall, M.T. Momol, S.E. Webb, T.G. Taylor, S.A. Smith, E.H. Simonne, and E. McAvoy. 2006. Tomato production in Florida. EDIS, 2006(3).

Padmanabhan, P., A. Cheema, and G. Paliyath. 2016. Solanaceous fruits including tomato, eggplant, and peppers, p. 24-32. In: C. Benjamin, M.F. Paul, and T. Fidel (eds.). Encyclopedia of Food and Health, doi:10.1016/b978-0-12-384 947-2.00696-6.

Peet, M.M. and G.W.H. Welles. 2005. Greenhouse tomato production, p. 257. In E. Heuvelink (ed.). Tomatoes. CAB eBooks, doi: 10.1079/ 9780851993966.0257.

Pickens, J.M., J.J. Danaher, J.L. Sibley, J.A. Chappell, and T.R. Hanson. 2020. Integrating greenhouse cherry tomato production with biofloc tilapia production. Horticulturae 6(3):44, doi: 10.3390/horticulturae6030044.

Radin, A.M. 2016. High Tunnel Tomato Variety Report URI 2016. 14 May 2021. <http:// digitalcommons.uri.edu/riaes_bulletin/18http:// digitalcommons.uri.edu/riaes_bulletin/18>.

Reimers, K.J. and D.R. Keast. 2016. Tomato consumption in the United States and its relationship to the US Department of Agriculture Food Pattern: Results from what we eat in America 2005-2010. Nutr. Today 51(4):198-205, doi: $10.1097 /$ nt.0000000000000152.

Sadler, G., J. Davis, and D. Dezman. 1990. Rapid extraction of lycopene and $\beta$-carotene from reconstituted tomato paste and pink grapefruit homogenates. J. Food Sci. 55(5):1460-1461, doi: 10.1111/j.1365-2621.1990.tb03958.x.

Saltveit, M.E. 2005. Fruit ripening and fruit quality. Crop Prod. Sci. Hort. 13:145, doi: 10.1079/ 9780851993966.0145.
Savvas, D., K. Akoumianakis, I. Karapanos, C.K. Kontopoulou, G. Ntatsi, A. Liontakis, and A. Akoumianakis. 2015. Recharging Greek youth to revitalize the agriculture and food sector of the Greek economy. Final Report Sectoral Study, 5:1-214.

Singh, H. and B. Dunn. 2016. Electrical conductivity and $\mathrm{pH}$ guide for hydroponics, p. 5. Oklahoma Cooperative Extension Fact Sheets, HLA-6722. Oklahoma State University, Division of Agricultural Sciences and Natural Resources. 14 May 2021. <https://extension.okstate. edu/fact-sheets/electrical-conductivity-and-phguide-for-hydroponics.html>.

Singh, H., B.K. Northup, G.S. Baath, P.P. Gowda, and V.G. Kakani. 2019. Greenhouse mitigation strategies for agronomic and grazing lands of the US Southern Great Plains. Mitig. Adapt. Strateg. Glob. Chang. 1-35, doi: 10.1007/s11027-01909902-4.

Setyorini, D. 2021. Terpenoids: Lycopene in tomatoes. IntechOpen. 14 May 2021. <https://www. intechopen.com/online-first/terpenoids-lycopenein-tomatoes $>$. doi: 10.5772/intechopen.97126.

Thaxton, B.R. and R.C. Hochmuth. 2015. Tomato cultivar selection considerations for open-field and protected culture in North Florida. 14 May 2021. < https://edis.ifas.ufl.edu/pdffiles/HS/HS 127300.pdf $>$.

Warren, N.D., R.G. Sideman, and R.G. Smith. 2015. Performance of high tunnel tomato cultivars in northern New England. HortTechnology 25(1):139-146, doi: 10.21273/horttech.25.1.139.

Wismer, W.V. 2014. Consumer eating habits and perceptions of fresh produce quality, p. 31-52. In: Postharvest handling. Academic Press, San Diego, CA, doi: 10.1016/b978-0-12-4081376.00003-X.

Yeshiwas, Y. and K. Tolessa. 2018. Postharvest quality of tomato (Solanum lycopersicum) varieties grown under greenhouse and open field conditions. Intl. J. Biotechnol. Mol. Biol. Res. 9(1):1-6, doi: 10.5897/ijbmbr2015.0237. 